\title{
LARANGAN PENGURUS (FUNGSIONARIS) PARTAI POLITIK SEBAGAI BAKAL CALON ANGGOTA DEWAN PERWAKILAN DAERAH PADA PEMILU 2019
}

\author{
Tohadi, Dian Eka Prastiwi, Reni Suryani \\ Fakultas Hukum Universitas Pamulang \\ E-Mail: mohtohadi@gmail.com
}

\begin{abstract}
Abstrak
Penelitian ini untuk menjawab dan mendeskripsikan: 1) bagaimana pertimbangan dan amar Putusan MK No. 30/PUU-XVI/2018 dan Putusan MA No. $65 \mathrm{P} / \mathrm{HUM} / 2018$ terkait larangan bagi pengurus partai sebagai balon anggota DPD pada Pemilu 2019; dan 2) Apa yang menyebabkan adanya perbedaan dalam pertimbangan pada Putusan MK No. 30/PUU-XVI/2018 dan Putusan MA No. 65 $\mathrm{P} / \mathrm{HUM} / 2018$ dimaksud. Peneliti menggunakan penelitian hukum sosiologis (socio-legal research) untuk menggambarkan masalah-masalah penelitian dengan menggunakan data sekunder diperkuat dengan data primer. Peneliti memberikan kesimpulan, pertama, Putusan MK No. 30/PUU-XVI/2018 dan Putusan MA No. 65 P/HUM/2018 keduanya menegaskan adanya larangan bagi pengurus partai sebagai balon anggota DPD. Meskipun ada perbedaan terkait pemberlakuannya pada Pemilu 2019. Menurut Putusan MK, ketentuan tersebut sudah dikenakan pada Pemilu 2019, sedangkan menurut Putusan MA ketentuan dimaksud tidak memiliki kekuatan hukum mengikat jika diberlakukan pada Pemilu 2019. Kedua, adanya perbedaan kedua putusan lembaga kekuasaan kehakiman itu karena adanya penafsiran yang berbeda mengenai pengertian tahap pencalonan anggota DPD pada Pemilu 2019.
\end{abstract}

Kata Kunci: fungsionaris; partai politik; DPD; pemilu 2019.

\section{Abstract}

This research is to answer and describe: 1) how are the considerations and dictums of the Constitutional Court Decision Number 30 / PUU-XVI / 2018 and the Supreme Court Decision Number 65 P / HUM / 2018 related to the prohibition on political party administrators (functionaries) as prospective DPD members in the General Election 2019; and 2) What causes the differences in the consideration of the Constitutional Court Decision Number 30 / PUU-XVI / 2018 and Supreme Court Decision Number 65 P / HUM / 2018 regarding the prohibition for political party administrators (functionaries) as prospective candidates for DPD members in the 2019 Election. This research is a socio-legal research to describe research problems using secondary data reinforced by primary data. The researcher concludes that, first, the Constitutional Court Decision Number 30 / PUU-XVI / 2018 and the Supreme Court Decision Number 
65 P / HUM / 2018 both emphasize the prohibition for political party administrators (functionaries) as prospective DPD members. Even though there are differences regarding their enforcement in the 2019 Election. According to the Constitutional Court Decision, these provisions have already been imposed in the 2019 Election, whereas according to the Supreme Court Decision the provisions in question do not have binding legal force if applied in the 2019 Election. Second, there are differences between the decisions of the judicial authorities because different interpretations regarding the meaning of the stage of nomination for DPD members in the 2019 Election.

Keywords: Functionaries; Political Party; DPD; the 2019 Election.

\section{Pendahuluan}

Diskursus larangan bagi pengurus (fungsionaris) partai politik (selanjutnya disebut: pengurus partai) sebagai bakal calon anggota Dewan Perwakilan Darah (selanjutnya disingkat: balon anggota DPD) pada Pemilihan Umum Tahun 2019 (selanjutnya disingkat: Pemilu 2019) menjadi perhatian publik. Hal ini menyusul adanya putusan lembaga kekuasaan kehakiman yang berbeda. Yaitu Putusan Mahkamah Agung Nomor 65 P/HUM/2018 bertanggal 25 Oktober 2018 (selanjutnya disebut: Putusan MA No. 65 P/HUM/2018) yang memiliki pertimbangan hukum dan putusan yang berbeda dengan Putusan Mahkamah Konstitusi Nomor 30/PUU-XVI/2018 bertanggal 23 Juli 2018 (selanjutnya disebut: Putusan MK No. 30/PUU-XVI/2018) terkait larangan bagi pengurus partai sebagai balon anggota DPD pada Pemilu 2019.

Sebelumnya, amar atau diktum (dictum) dari Putusan MK No. 30/PUU$\mathrm{XVI} / 2018$ a quo pada pokoknya menyatakan bahwa frasa "pekerjaan lain" dalam Pasal 182 huruf I UU No. 7 Tahun 2017 tentang Pemilihan Umum (disebut: UU Pemilu) "bertentangan dengan UUD 1945 dan tidak mempunyai kekuatan hukum mengikat secara bersyarat sepanjang tidak dimaknai mencakup pula pengurus (fungsionaris) partai politik."

MK dalam pertimbangan hukumnya menyatakan larangan pengurus partai politik mendaftar balon anggota DPD tersebut dampaknya sudah mengena kepada balon anggota DPD yang sudah mendaftar untuk Pemilu 2019. MK kemudian memberikan solusi agar Komisi Pemilihan Umum (KPU) memberikan waktu kepada calon anggota DPD yang mendaftarkan diri pada Pemilu 2019 diakui tetap sah sepanjang mengundurkan diri sebagai pengurus partai. ${ }^{1}$

KPU telah menindaklanjutinya dengan menerbitkan Peraturan KPU (PKPU) Nomor 26 Tahun 2018 bertanggal 6 Agustus 2018 tentang Perubahan Kedua atas

\footnotetext{
${ }^{1}$ Vide Putusan MK Nomor 30/PUU-XVI/2018 tanggal 23 Juli 2018, alinea [3.17] hlm. 51.
} 
Peraturan KPU Nomor 14 Tahun 2018 tentang Pencalonan Perseorangan Peserta Pemilu Anggota Dewan Perwakilan Daerah (selanjutnya disebut: PKPU No. 26 Tahun 2018). Ketentuan Pasal 60A PKPU tersebut pada intinya mewajibkan balon anggota DPD untuk menyerahkan Surat Keputusan Pemberhentian dari Pimpinan Partai dan/ atau Surat Pernyataan Pengunduran Diri yang bersangkutan, dengan sanksi jika tidak dipenuhi, maka tidak ada dalam dalam Daftar Pemilih Tetap (DPT). Namun kemudian, keluar Putusan MA No. 65 P/HUM/2018 menyatakan ketentuan Pasal 60A PKPU Nomor 26 Tahun 2018 "bertentangan dengan peraturan perundang-undangan yang lebih tinggi", dan menyatakan ketentuan a quo "tetap mempunyai kekuatan hukum mengikat dan berlaku umum sepanjang tidak diberlakukan surut terhadap Peserta Pemilu Anggota Dewan Perwakilan Daerah Tahun 2019."Timbul perdebatan di tengah masyarakat bahkan di kalangan ahli hukum mengenai putusan lembaga kekuasaan kehakiman mana yang harus diikuti, apakah Putusan MK No. 30/PUUXVI/2018 atau Putusan MA No. 65 P/HUM/2018.

\section{Permasalahan}

Permasalahan yang diangkat peneliti, yaitu Pertama, bagaimanakah pertimbangan dan amar Putusan MK No. 30/PUU-XVI/2018 dan Putusan MA No. 65 P/HUM/2018 terkait dengan larangan bagi pengurus partai sebagai balon DPD pada Pemilu 2019 ?; dan Kedua, Apa yang menyebabkan adanya perbedaan dalam pertimbangan pada Putusan MK No. 30/PUU-XVI/2018 dan Putusan MA No. $65 \mathrm{P} / \mathrm{HUM} / 2018$ itu ?.

\section{Metode Penelitian}

Peneliti menggunakan penelitian hukum sosiologis (socio-legal research) yang memandang hukum sebagai gejala sosial bersifat empiris, ${ }^{2}$ dengan menganalisisnya secara deskriptif ${ }^{3}$ dan kualitatif. 4 Penelitian akan menggambarkan masalah-masalah yang menjadi tujuan penelitian sebagaimana mestinya, dengan menggunakan data sekunder dan diperkuat dengan data primer. Peneliti mengkaji Putusan MK No. 30/PUU-XVI/2018 dan Putusan MA No. $65 \mathrm{P} / \mathrm{HUM} / 2018$ terkait dengan larangan bagi pengurus partai sebagai balon anggota DPD pada Pemilu 2019 kemudian melakukan wawancara secara mendalam kepada KPU.

${ }^{2}$ Amiruddin dan H. Zainal Asikin, Pengantar Metode Penelitian Hukum, PT RajaGrafindo Persada, Jakarta, 2004, hlm.133-134.

${ }^{3}$ Soerjono Soekanto, Pengantar Penelitian Hukum, UI Press, Jakarta, 1982, hlm. 49, 53, dan 96. Lihat juga Suharsini Arikunto, Manajemen Penelitian, PT Rineka Cipta, Jakarta, 1993, hlm. 309, dan Erna Widodo dan Mukhtar, Konstruksi Ke Arah Penelitian Deskriptif, Avyrouz, Yogyakarta, 2000, hlm. 15.

${ }^{4}$ Wisnu Jatmiko dkk, Panduan Penulisan Artikel Ilmiah, Fakultas IImu Komputer Universitas Indonesia, Depok, 2015, hlm. 60. 


\section{Pembahasan}

Perkembangan Negara Indonesia bisa dilihat dari sistem pemerintahannya. Pemilu 2019 adalah sebuah proses politik untuk mewujudkan desain sistem ketataneegaraan setelah adanya amandemen UUD 1945. Sebagaimana kita maklum, desain dari sistem ketatanegaraan Indonesia setekah perubahan UUD 1945 terkait dengan sistem pemilu adalah adanya jaminan konstitusional tentang pemilu yang memuat keharusan pemilu diadakan secara periodik per lima tahun-an, asas Pemilu "luber dan jurdil", lembaga neegara yang keanggotaannya diisi melalui pemilu (yaitu DPR, DPD, DPRD, dan Presiden/Wakil Presiden), peserta pemilu (Parpol/Perorangan), dan penyelenggara pemilu yaitu Komisi Pemilihan Umum (KPU) (Pasal 22E UUD 1945).

Pemilu 2019 ini merupakan pemilu ke-4 (empat) setelah dilakukannya Amandemen UUD 1945 dengan berbagai undang-undang organik (UU Parpol, UU Pemilu, UU Pemilihan Presiden atau Wakil Presiden, UU Susduk, dan UU MK) yang didesaian secara tergesa-gesa dan penuh tarik menarik kepentingan partai politik di DPR yang cenderung ingin mempertahankan status quo dan berorientasi jangka pendek, sehingga berbagai UU organik tersebut belum cukup ideal untuk mewujudkan ketatanegaraan pasca Amandemen UUD 1945 yang juga belum ideal. Hal ini, sebagaimana dikatakan Abdul Mukthie Fajar ${ }^{5}$ bisa dilihat dari UU Parpol, UU Pemilu (sistem proporsional setengah hati), UU Pilpres (persyaratan dan tidak terakomodasinya calon independen), dan UU MK (Pembatasan UU yang bisa direview di MK).

Dalam Undang-Undang Nomor 7 Tahun 2017 tentang Pemilihan Umum (selanjutnya disebut: UU Pemilu) yang menjadi dasar penyelenggaraan Pemilu 2019 tidak ada larangan mengenai anggota DPD yang sekaligus sebagai pengurus partai. Ketentuan di atas berbeda dengan pengaturan yang ada pada UU No.12 Tahun 2003 tentang Pemilu Anggota DPR, DPD, dan DPRD (disebut: UU No. 12 Tahun 2003) sebagai dasar penyelenggaraan Pemilu 2004.

Pada Pasal 22 E Ayat (4) UUD 1945 dijelaskan bahwa, "Peserta Pemilihan Umum untuk memilih anggota DPD adalah perseorangan". Para Pembentuk Undang-Undang menerjemahkan ini ke dalam UU No. 12 Tahun 2003 bahwa anggota DPD harus memenuhi syarat calon, yaitu, "tidak menjadi pengurus partai politik sekurang-kurangnya empat tahun dihitung sampai dengan tanggal pengajuan calon”. Akan tetapi setelah diberlakukannya UU No. 10 Tahun 2008 tentang Pemilu Anggota DPR, DPD, dan DPRD (UU No. 10 Tahun 2008) dalam pasal 12 maupun penjelasannya tidak lagi mengatur persyaratan non partai sebagai calon anggota DPD. Dengan dihapusnya larangan pengurus bagi calon

${ }^{5}$ Abdul Mukthie Fajar, Hukum Konstitusi dan Mahkamah Konstitusi, Konstitusi Press, Jakarta, 2006, hlm. 95. 
anggota DPD menyebabkan adanya konsekuensi terhadap jumlah anggota DPD yang sekaligus merupakan pengurus partai. UU No. 10 Tahun 2008 pun selanjutnya diubah dengan UU No. 8 Tahun 2012 tentang Pemilu Anggota DPR, DPD, dan DPRD (UU No. 8 Tahun 2012). Akan tetapi, sebagaimana dalam Pasal 67, tidak mengubah persyaratan calon anggota DPD. Ketentuan di atas diperkuat dengan adanya UU No. 7 Tahun 2017 tentang Pemilihan Umum (selanjutnya disebut: UU No. 7 Tahun 2017 atau UU Pemilu) yang juga tidak menentukan larangan bagi anggota DPD yang sekaligus pengurus partai. Sebagai implikasinya, banyak anggota ataupun pengurus partai mendaftarkan dirinya sebagai calon perseorangan untuk menjadi anggota DPD. Dalam catatan Indonesian Parliamentary Center (IPC) pada periode 2014-2019 ada sebanyak 70 dari 132 anggota DPD berafiliasi dengan partai. Kemudian, ada sejumlah 8 anggota DPD sekaligus sebagai sebagai pengurus partai. ${ }^{6}$

\section{Pertimbangan dan Amar Putusan Mahkamah Konstitusi Nomor 30/PUU- $\mathrm{XVI} / 2018$}

Ketentuan UU No. 7 Tahun 2017 (atau UU Pemilu) terkait keanggotaan DPD telah dibawa uji materiil (constitutional review) ke MK dan telah dijatuhkan Putusan MK No. 30/PUU-XVI/2018. Putusan MK No. 30/PUU-XVI/2018 ini merupakan putusan dari adanya uji materiil (constitutional review) atas frasa "pekerjaan lain” pada Pasal 182 huruf I UU No. 7 Tahun 2017.

Ketentuan Pasal 182 huruf I UU Pemilu menyatakan Perseorangan sebagaimana dimaksud dalam Pasat 181 dapat menjadi Peserta Pemilu setelah memenuhi persyaratan: bersedia untuk tidak berpraktik sebagai akuntan publik, advokat, notaris, pejabat pembuat akta tanah, dan/atau tidak melakukan pekerjaan penyedia barang dan jasa yang berhubungan dengan keuangan negara serta pekerjaan lain yang dapat menimbulkan konflik kepentingan dengan tugas, wewenang, dan hak sebagai anggota DPD sesuai ketentuan peraturan perundang-undangan;"

Mahkamah Konstitusi (Mahkamah) mengawali pertimbangannya dengan mengutip pertimbangan Putusan Mahkamah sebelumnya, yaitu Putusan MK No. 10/PUU-VI/2008.

Menurut Mahkamah, pertama, original intent pembentukan DPD tidak dimaksudkan untuk menghilangkan fungsi penting partai sebagai komunikasi dan agregasi politik. Pada kenyataannya partai tidak secara absolut mewakili kepentingan seluruh rakya. Kondisi ini juga terjadi misalnya di Amerika Serikat, ditandai dengan munculnya calon-calon presiden independen. Hal ini seiring berkembangya wacana (discourse) tentang deliberative democracy yang

${ }^{6}$ Indonesian Parliamentary Center, Jumlah Afiliasi Anggota DPD Dalam Partai Politik, http://ipc.or.id/wp-content/uploads/2017/04/garis.jpg. Diakses pada tanggal 18 Oktober 2020. 
tumbuh pertama kali pada abad ke-20, di mana membuka keterlibatan warga negara biasa (lay citizens) di samping peran kelompok elit yang diwakili partai. ${ }^{7}$ Kedua, adanya syarat tidak bolehnya "anggota DPD menjadi pengurus atau berasal dari pengurus partai" agar tidak ada perwakilan ganda (double representation) ketika menentukan keputusan politik terutama seperti perubahan Undang-Undang Dasar. Sebab, menurut mahkamah, pada satu sisi sesuai Pasal 2 ayat (1) UUD 1945 DPD merupakan anggota MPR, sedangkan sisi lain, merujuk Pasal 3 ayat (1) UUD 1945 bahwa, "MPR berwenang mengubah dan menetapkan Undang-Undang Dasar."8

Ketiga, menurut Mahkamah, sesuai dengan prinsip representation by election, DPD mencerminkan keberadaan golongan-golongan dalam masyarakat yang diwakili para tokoh yang menjadi anggota DPD. ${ }^{9}$ Dalam putusan Mahkamah berikutnya, yaitu Putusan MK No. 92/PUU-X/2012, Mahkamah menekankan keanggotaan DPD sebagai perwujudan wilayah (teritorial) yang membedakan dengan keanggotaan DPR dari partai. ${ }^{10} \mathrm{Hal}$ demikian sejalan dengan Putusan MK No. 79/PUU-XII/2014 yang pokoknya menegaskan keharusan keterlibatan secara maksimal DPD dalam proses legislasi "yang berkaitan dengan otonomi daerah, hubungan pusat dan daerah, pembentukan dan pemekaran serta penggabungan daerah, pengelolaan sumber daya ekonomi lainnya, serta perimbangan keuangan pusat dan daerah."11

Selanjutnya, Mahkamah mempertimbangkan Pasal 182 UU Pemilu. Menurut Mahkamah, dalam Pasal 182 UU Pemilu tidak ada ketegasan mengeni larangan pengurus partai menjadi calon anggota DPD. Oleh karenanya, Mahkamah berkewajiban untuk menjamin agar terwujud amanat Pasal 22D UUD yang menekankan DPD sebagai perwujudan daerah. ${ }^{12}$ Pasal 182 huruf I UU Pemilu tidak menjelaskan frasa "pekerjaan lain yang dapat menimbulkan konflik kepentingan dengan tugas, wewenang, dan hak sebagai anggota DPD sesuai dengan peraturan perundang-undangan". Hal ini, menurut Mahkamah, "menimbulkan ketidakpastian hukum mengenai boleh atau tidaknya perseorangan yang menjadi pengurus partai politik mencalonkan diri sebagai calon anggota DPD”, dengan demikian "bertentangan dengan Pasal 28D ayat (1) UUD 1945."13

Dalam pertimbangan selanjutnya, Mahkamah berpendirian "jika ditafsirkan dapat atau boleh", menjadi "bertentangan dengan hakikat DPD sebagai perwujudan daerah dan sekaligus berpotensi memunculkan adanya

\footnotetext{
${ }^{7}$ Putusan Mahkamah Konstitusi Nomor 30/PUU-XVI/2018 tanggal 23 Juli 2018 hlm. 45.

${ }^{7}$ Ibid.

${ }^{9}$ Ibid.

${ }^{10} \mathrm{lbid}$., hlm. 47.

${ }^{11} \mathrm{lbid} ., \mathrm{hlm} .48$.

12 lbid., hlm. 49.

13 Ibid., hlm. 49-50.
} 
perwakilan ganda (double representation)" di mana terdapat wakil partai yang ada di DPR maupun di DPD, yang berarti bertentangan dengan amanah Pasal 22D UUD 1945. Demikian pula, apabila dimaknai "tidak dapat atau tidak boleh", tapi tidak ada ketegasan dalam Pasal 182 huruf I UU Pemilu. Oleh karena itu, Mahkamah harus mempertegas, "Perseorangan warga negara Indonesia yang mencalonkan diri sebagai anggota DPD tidak boleh merangkap sebagai pengurus partai politik." 14

Mahkamah juga mempertegas dalam pertimbangannya, bahwa "pengurus Partai Politik" adalah: "Pengurus mulai dari tingkat pusat sampai tingkat paling rendah sesuai dengan struktur organisasi partai politik yang bersangkutan." 15 Mahkamah menekankan sehubungan telah dimulainya proses pendaftaran calon anggota DPD pada Pemilu 2019, maka bagi bakal calon anggota DPD sekaligus sebagai pengurus partai sudah terkena dampak putusan MK a quo. Namun demikian, menurut Mahkamah, "KPU dapat memberikan kesempatan kepada yang bersangkutan sepanjang telah menyatakan mengundurkan diri dari kepengurusan Partai Politik dibuktikan dengan pernyataan tertulis yang bernilai hukum perihal pengunduran diri dimaksud." Kemudian, Mahkamah melanjutkan, "Anggota DPD sejak Pemilu 2019 dan Pemilu-Pemilu setelahnya yang menjadi pengurus partai politik adalah bertentangan dengan UUD 1945."16

Pada akhirnya, Mahkamah menyatakan frasa "pekerjaan lain" dalam Pasal 182 huruf I UU No. 7 Tahun 2017 "bertentangan dengan UUD 1945 dan tidak mempunyai kekuatan hukum mengikat secara bersyarat sepanjang tidak dimaknai mencakup pula pengurus (fungsionaris) partai politik." 17

\section{Pertimbangan dan Amar Putusan Mahkamah Agung Nomor 65 P/HUM/2018}

Putusan MA No. 65 P/HUM/2018 tanggal 25 Oktober 2018 merupakan putusan atas perkara uji materiil (judicial review) atas PKPU No. 26 Tahun 2018. Menurut Mahkamah Agung (Mahkamah), pertanyaan hukum dalam permohonan uji materiil tersebut adalah apakah PKPU No. 26 Tahun 2018 dapat diterapkan pada pencalonan anggota DPD pada Pemilu 2019 yang tahapannya telah dimulai dan masih sedang berlangsung. 18 Namun sebelum itu, Mahkamah mempertimbangkan terlebih dahulu mengenai kewenangan KPU membuat PKPU No. 26 Tahun 2018 sebagai tindak lanjut dari Putusan MK, padahal setelah adanya Putusan MK tersebut Pembentuk UU (DPR dan Presiden) sendiri belum melakukan perubahan atas UU Pemilu.

\footnotetext{
14 Ibid., hlm. 50 .

15 Ibid., hlm. 51.

16 Ibid.

17 Ibid., hlm. 52.

18 Putusan Mahkamah Agung Nomor 65 P/HUM/2018 tanggal 25 Oktober 2018 hlm. 33.
} 
Menurut Mahkamah, meskipun sesuai Pasal 10 ayat (2) UU No. 12 Tahun 2011 tentang Pembentukan Peraturan Perundang-Undangan (disingkat UU No. 12 Tahun 2011) DPR atau Presiden yang menindaklanjuti putusan MK, akan tetapi penafsiran akan hal itu harus didudukkan dalam konteks yang lebih luas dengan mengaitkan pada norma hukum lainnya dan realitas ketika Putusan MK dijatuhkan agar diperoleh suatu pemahaman hukum yang komprehensif. ${ }^{19}$

Putusan MK, menurut Mahkamah, merupakan norma bersifat umum sebagai penerapan dan pembentukan hukum berlandaskan konstitusi, yang berkedudukan sederajat dengan Undang-undang. Maka putusan MK dapat ditindaklanjuti secara langsung oleh pihak terkait tanpa harus menunggu lebih dulu DPR atau Presiden. Hal tersebut, kata Mahkamah, dapat dilihat dari fakta konvensi ketatanegaraan ketika kementerian dan lembaga negara dapat secara langsung menindaklanjuti putusan MK mulai saat diucapkan. Dengan demikian, lanjut Mahkamah, KPU berwenang membuat PKPU No. 26 Tahun 2018 untuk menindaklanjuti putusan MK tersebut. ${ }^{20}$ Pertanyaan hukum selanjutnya, menurut Mahkamah, "Apakah peraturan tersebut dapat diterapkan pada tahapan Pemilu Anggota DPD Tahun 2019 yang lebih dahulu telah dilaksanakan?"

Merujuk pada Lampiran Peraturan KPU Nomor 7 tahun 2017 Tentang Tahapan, Program dan Jadwal Penyelenggaraan Pemilihan Umum 2019 (disingkat: PKPU No. 7 Tahun 2017), bahwa pendaftaran dan verifikasi calon anggota DPD, dibuka mulai tanggal 26 Maret 2018 hingga 8 April 2018. Kemudian, diakhiri dengan Pengumuman Daftar Calon Tetap (DCT) mulia sejak tanggal 21-23 September 2018. ${ }^{21}$

Adanya constitutional review atas frasa "pekerjaan lain" pada Pasal 182 huruf I UU Pemilu diterima pada tanggal 4 April 2018 di Kepaniteraan MK sebagaimana Akta Penerimaan Berkas Permohonan No. 59/PAN.MK/2018, selanjutnya didaftar pada tanggal 9 April 2018 dalam Buku Registrasi Perkara Konstitusi dengan No. 30/PUU-XVI/2018. ${ }^{22}$

Kemudian, MK memutuskan permohonan tersebut pada tanggal 23 Juli 2018, dalam Putusan MK No. 30/PUU-XVI/2018. ${ }^{23}$

Selanjutnya, menindaklanjuti Putusan MK di atas, KPU mengeluarkan PKPU No. 26 Tahun 2018 bertanggal 6 Agustus 2018, kemudian diundangkan tanggal 9 Agustus 2018. ${ }^{24}$ Menurut Mahkamah, kronologis terbitnya PKPU No. 26 Tahun 2018, yaitu: Pertama, Pendaftaran dan verifikasi calon anggota DPD dilaksanakan terlebih dulu daripada pendaftaran Permohonan Uji Materiil No.

\footnotetext{
19 Ibid., hlm. 36.

20 Ibid.

21 Ibid., hlm. 38.

22 Ibid., hlm. 39.

23 Ibid.

24 Ibid.
} 
30/PUU-XVI/2018; Kedua,KPU menindaklanjuti Putusan MK dengan menerbitkan PKPU No. 26 Tahun 2018 dan memberlakukannya kepada calon anggota DPD yang sudah mendaftarkan diri pada Pemilu 2019. Yaitu dengan mewajibkan kepada "Bakal Calon Anggota DPD yang merupakan pengurus partai politik tingkat pusat, pengurus partai politik tingkat provinsi dan pengurus partai politik tingkat kabupaten/kota harus menyerahkan surat pernyataan pengunduran diri sebagai pengurus partai politik ke KPU setempat." 25

Menurut Mahkamah, masalah utama dalam uji materiil ini adalah adanya konflik antara norma hukum dengan asas hukum. Di satu sisi, ada Putusan MK yang berkedudukan sederajat undang-undang berhadapan dengan asas yang menentukan suatu peraturan perundang-undangan tidak dapat berlaku surut (non retro active). ${ }^{26}$ Mahkamah menyimpulkan Putusan MK yang "menyatakan undang-undang, bagian dari undang-undang, pasal, atau ayat bertentangan dengan UUD 1945 dan tidak mempunyai kekuatan hukum mengikat", maka akibat hukumya berlaku ke depan (prospektif) mulai saat putusan diucapkan (ex nunc), tetapi tidak berlaku (retrospektif atau ex tunc). Terhadap hal itu, maka Mahkamah Agung dan Pengadilan di bawahnya terikat untuk mengabaikannya. ${ }^{27}$

Mahkamah menilai KPU menerapkan secara surut (retro active) atas Pasal 60A PKPU No. 26 Tahun 2018 sehingga tidak efektif, karena membebankan suatu kewajiban baru yang tidak ada sebelumnya bagi balon anggota DPD pada tahapan program, dan penyelenggaran pemilu yang telah dilaksanakan dan sedang berlangsung. Menurut Mahkamah, sebaliknya, akan menjadi efektif kalau ada putusan MK lebih awal dan selanjutnya dibuat PKPU tersebut. ${ }^{28}$ Dengan demikian, pemberlakuan Ketentuan Pasal 60A PKPU No. 26 Tahun 2018, menurut Mahkamah, tidaklah sejalan dengan prinsip Putusan MK yang bersifat prospektif sebagaimana diatur dalam pasal $47 \mathrm{UU}$ MK. Hal ini, sangat bertentangan dengan asas-asas Pembentukan Peraturan Perundang-undangan yang baik. ${ }^{29}$

Dalam upaya menjamin kepastian hukum, Mahkamah berpendapat, ketentuan a quo yang telah dinyatakan bertentangan dengan Pasal 5 huruf $\mathrm{d}$ dan Pasal 6 ayat (1) huruf i UU No. 12 Tahun 2011 adalah "tetap mempunyai kekuatan hukum mengikat sepanjang tidak diberlakukan surut" terhadap calon anggota DPD yang telah mendaftarkan diri pada Pemilu 2019 berdasarkan PKPU No. 7 Tahun 2017. ${ }^{30}$ Selain untuk menjamin kepastian hukum, lanjut Mahkamah, juga untuk menjamin kelancaran proses Pemilu 2019 dan mencegah

\footnotetext{
25 Ibid., hlm. 40-41.

${ }^{26}$ Ibid., hlm. 42.

27 Ibid., hlm. 43-44.

28 Ibid., hlm. 44.

29 Ibid., hlm. 45.

30 Ibid.
} 
kemungkinan timbulnya gugatan dari pihak-pihak dirugikan dengan diberlakukannya PKPU dimaksud. ${ }^{31}$

Pada akhirnya Mahkamah memutuskan yang amar pokoknya menyatakan ketentuan Pasal 60A PKPU No. 26 Tahun 2018 “bertentangan dengan peraturan perundang-undangan yang lebih tinggi yakni Pasal 5 huruf $d$ dan Pasal 6 ayat (1) huruf i Undang-Undang Nomor 12 Tahun 2011 tentang Pembentukan Peraturan Perundang-Undangan"; dan menyatakan ketentuan Pasal 60A PKPU tersebut "tetap mempunyai kekuatan hukum mengikat dan berlaku umum sepanjang tidak diberlakukan surut" terhadap balon anggota DPD yang telah mengikuti tahapan pencalonan pada Pemilu 2019 berdasarkan PKPU No. 7 Tahun 2017."32

\section{Faktor Penyebab Adanya Perbedaan Dalam Pertimbangan Pada Putusan MK Nomor 30/PUU-XVI/2018 dan Putusan MA Nomor 65 P/HUM/2018}

Baik MK, MA maupun KPU masing-masing telah memiliki kewenangan atribusi. Yaitu kewenangan yang melekat dan dimiliki sebagai pemberian Undang-Undang Dasar 1945 (UUD 1945) atau Undang-Undang (UU). ${ }^{33}$ MK dan MA, sesuai peraturan perundang-undangan, memiliki kewenangan di bidang kekuasaan kehakiman atau mengadili, yang menurut Prajudi Atmosudirdjo, disebut sebagai kompetensi atau yurisdiksi. ${ }^{34}$

Sudikno Mertokusumo mendefinisikan wewenang mutlak atau kompetensi absolut, sebagai "Wewenang badan pengadilan dalam memeriksa jenis perkara tertentu yang secara mutlak tidak dapat diperiksa oleh badan pengadilan lain." 35

Wewenang mutlak untuk menjawab pertanyaan: apakah pengadilan tertentu itu memiliki wewenang memeriksa jenis perkara dan bukan menjadi wewenang dari pengadilan lain. Wewenang ini, menurutnya, disebut atribusi kekuasaan kehakiman. ${ }^{36} \mathrm{M}$. Yahya Harahap menyebut dengan atribusi kekuasaan (atributive competentie, attributive jurisdiction) sebagai faktor yang membedakan atau membagi yurisdiksi sesuai lingkungan peradilan. Atribusi kekuasaan, lanjutnya, "melahirkan kekuasaan atau kewenangan absolut bagi masing-masing lingkungan peradilan." 37 Adapun mengenai wewenang nisbi atau kompetensi relatif, dijelaskan Sudikno Mertokusumo berkenaan atas wilayah

\footnotetext{
31 Ibid., hlm. 45-46.

32 Ibid., hlm. 46-47.

${ }^{33}$ Mengenai kewenangan atribusi dapat dilihat pada Ridwan HR, Hukum Administrasi Negara, Cetakan ke-15, PT RajaGrafindo Persada, Depok, 2018, hlm. 98-99.

34 Ibid.

35 Sudikno Mertokusumo, Hukum Acara Perdata Indonesia, Edisi Revisi, Cahaya Atma Pustaka, Yogyakarta, 2013, hlm. 62. 36 Ibid.

${ }^{37}$ M. Yahya Harahap, Hukum Acara Perdata Tentang Gugatan, Persidangan, Penyitaan, Pembuktian, dan Putusan Pengadilan, Sinar Grafika, Jakarta, 2011, hlm. 179.
} 
hukum suatu pengadilan. Wewenang ini, lanjutnya, menyangkut dengan “pembagian kekuasaan kehakiman (distribusi kekuasaan kehakiman)." 38

Merujuk pada Pasal 10 ayat (1) huruf a UU No. 24 Tahun 2003 tentang Mahkamah Konstitusi sebagaimana telah diubah terakhir dengan UU No. 7 Tahun 2020 tentang Perubahan Ketiga Atas UU No. 24 Tahun 2003, dan Pasal 29 ayat (1) huruf a UU No. 48 Tahun 2009 tentang Kekuasaan Kehakiman, MK memiliki kewenangan antara lain, "mengadili pada tingkat pertama dan terakhir yang putusannya bersifat final untuk: a. menguji undang-undang terhadap UndangUndang Dasar Negara Republik Indonesia Tahun 1945." Dengan demikian, MK berwenang melakukan uji materiil atas frasa "pekerjaan lain" pada Pasal 182 huruf I UU Pemilu. MA, merujuk pada UU No. 48 Tahun 2009 tentang Kekuasaan Kehakiman, UU No. 14 Tahun 1985 tentang Mahkamah Agung sebagaimana telah diubah dengan UU No. 5 Tahun 2004 dan terakhir dengan UU No. 3 Tahun 2009 memiliki kewenangan untuk melakukan uji materiil atas PKPU No. 26 Tahun 2018 bertanggal 6 Agustus 2018 tentang Perubahan Kedua atas PKPU Nomor 14 Tahun 2018 tentang Pencalonan Perseorangan Peserta Pemilu Anggota DPD.

Menarik dicatat di sini, terkait kewenangan MA melakukan uji materiil atas PKPU PKPU No. 26 Tahun 2018. Putusan MA No. 65 P/HUM/2018, menurut kacamata hukum Pan Mohamad Faiz dan Muhammad Reza Winata, dari sisi formal konstitusional sejalan dengan kewenangan MA berdasarkan peraturan perundang-undangan, namun "secara substansi telah bertentangan dengan tafsir konstitusional yang telah diputuskan MK." 39 Demikian halnya, mendasarkan pada UU No. 15 Tahun 2011 tentang Penyelenggara Pemilihan Umum dan UU No. 7 Tahun 2017 tentang Pemilihan Umum, KPU berwenang membuat peraturan sebagai pelaksanaan dari ketentuan yang diamanatkan oleh undang-undang khususnya terkait Pemilu.

Dalam pandangan hukum peneliti, sikap dan langkah KPU menindaklanjuti Putusan MK No. 30/PUU-XVI/2018 bertanggal 23 Juli 2018 dengan menerbitkan Pasal 60A PKPU Nomor 26 Tahun 2018 bertanggal 6 Agustus 2018 adalah benar secara hukum. Hal ini karena, selain KPU memiliki kewenangan atribusi membuat peraturan sebagai pelaksanaan dari undangundang, juga karena materi dalam Pasal 60A PKPU No. 26 Tahun 2018 bertanggal 6 Agustus 2018 sejalan dengan Putusan MK No. 30/PUU-XVI/2018 bertanggal 23 Juli 2018. Denny Indrayana dan Zainal Arifin Mochtar mengemukakan bahwa Putusan MK memiliki 'kekuatan mengikat' berarti secara langsung berlaku mengikat atas semua wilayah Indonesia (erga omnes). Pada sisi lain, menurutnya, kedudukan hakim MK sebagai negative legislator

38 Sudikno Mertokusumo, Op. Cit., 2013, hlm. 65.

${ }^{39}$ Pan Mohamad Faiz dan Muhammad Reza Winata, "Respons Konstitusional Larangan Calon Anggota Dewan Perwakilan Daerah sebagai Pengurus Partai Politik", Jurnal Konstitusi, Volume 16, Nomor 3, September 2019, hlm. 550. 
berakibat putusan MK memiliki kedudukan hukum seperti halnya hukum yang dibentuk DPR dan Presiden. ${ }^{40}$ Dalam pendapat Fajar Laksono Soeroso makna mengikat tercermin dalam sifat final dari putusan MK tersebut. Menurutnya, putusan MK merupakan putusan pada tingkat pertama dan terakhir, yang menegaskan tidak adanya upaya hukum selanjutnya dan memperoleh kekuatan hukum mengikat untuk dilaksanakan. ${ }^{41}$

Sedangkan Maruarar Siahaan menegaskan pandangannya bahwa: "Putusan tingkat pertama dan terakhir yang final tersebut memperoleh kekuatan hukum tetap sejak diucapkan dalam sidang terbuka untuk umum yang bersifat erga omnes, yaitu sebuah putusan yang akibat hukumnya mengikat semua pihak." 42 Dalam nada yang sama, Mohammad Agus Maulidi menyatakan kekuatan final dan mengikat dari putusan MK lahir sejak diucapkan dalam sidang pleno yang terbuka untuk umum. Menurutnya, putusan MK untuk menyelesaikan perkara dan memberikan kepastian hukum. Hal ini oleh karena perkara yang diadili MK merupakan, "perkara yang berkaitan dengan ketatanegaraan, sehingga membutuhkan kepastian hukum dan terikat dengan limitasi waktu agar tidak mengganggu keberlangsungan agenda ketatanegaraan." 43 Dengan demikian, menurut peneliti, dari sisi kekuatan mengikat dan sifat erga omnes Putusan MK, maka langkah KPU menindaklanjuti Putusan MK memiliki pijakan hukum yang benar.

Sebaliknya, sikap dan langkah KPU yang tidak menindaklanjuti Putusan MA No. 65 P/HUM/2018 juga tidak bertentangan dengan hukum. Karena sejalan dengan tafsir konstitusional MK. Hal itu karena Putusan MA No. 65 P/HUM/2018 dijatuhkan pada tanggal 25 Oktober 2018 di mana pencalonan anggota DPD telah selesai seiring dengan adanya penetapan Daftar Calon Tetap (DCT), yaitu berlangsung tanggal 21-23 September 2018.

Pencalonan anggota DPD, menurut PKPU No. 7 Tahun 2017 yang telah diubah dengan PKPU No. 5 Tahun 2018 dan terakhr diubah dengan PKPU No. 32 Tahun 2018, terdiri dari tahapan pendaftaran dan verifikasi calon anggota DPD yang dimulai sejak tanggal 26 Maret 2018 hingga 8 April 2018 kemudian diakhiri dengan Pengumuman DCT yang berlangsung sejak tanggal 21 September 2018 sampai dengan 23 September 2018. Hal yang sama sebagaimana dikatakan oleh

40 Denny Indrayana dan Zainal Arifin Mochtar, “Komparasi Sifat Mengikat Putusan Judicial Review Mahkamah Konstitusi dan Pengadilan Tata Usaha Negara”, Jurnal Mimbar Hukum, Volume 19, Nomor 3, Oktober 2007, hlm. 441.

${ }^{41}$ Fajar Laksono, dkk., "Implikasi dan Implementasi Putusan Mahkamah Konstitusi Nomor 5/PUUX/2012 tentang SBI atau RSBI”, Jurnal Konstitusi, Volume 10, Nomor 4, Desember 2013, hlm. 739.

42 Maruarar Siahaan, “Peran Mahkamah Konstitusi Dalam Penegakan Hukum Konstitusi”, Jurnal Hukum, Nomor 3, Volume, 16 Juli 2009, hlm. 359.

${ }^{43}$ Mohammad Agus Maulidi, "Problematika Hukum Implementasi Putusan Final dan Mengikat ahkamah Konstitusi Perspektif Negara Hukum”, Jurnal Hukum lus Quia lustum, No. 4 Vol. 24 Oktober 2017, hlm. 554. 
Ketua KPU Arief Budiman. KPU, menurutnya, tidak menindaklanjuti Putusan MA No. 65 P/HUM/2018 karena menurut KPU, adanya larangan bagi pengurus partai sebagai calon anggota DPD sebagaimana diatur dalam Pasal 60A PKPU No. 26 Tahun 2018 tidaklah berlaku surut. Selain itu, KPU tetap mengacu pada Putusan MK No. 30/PUU-XVI/2018 bertanggal 23 Juli 2018. "Ketentuan Pasal Pasal 60A PKPU Nomor 26 Tahun 2018 mencantumkan ketentuan yang diputuskan oleh MK", demikian kata Ketua KPU Arief Budiman. ${ }^{44}$

Berbeda dari sudut pandang dengan temuan Pan Mohamad Faiz dan Muhammad Reza Winata yang menyimpulkan faktor komunikasi sebagai faktor utama sebagai alasan adanya perbedaan antara Putusan MA dan MK. ${ }^{45}$ Peneliti berkesimpulan bahwa adanya perbedaan pertimbangan hukum antara MK dan MA karena adanya perbedaan memahami pengertian tahap pencalonan anggota DPD.

\section{Simpulan}

Berdasarkan paparan sebagaimana di atas, dapatlah ditarik kesimpulan, pertama, Putusan MK No. 30/PUU-XVI/2018 menyatakan pengurus (fungsionaris) partai politik tidak boleh menjadi calon anggota DPD dan larangan tersebut sudah diberlakukan bagi pengurus partai yang mencalonkan diri pada Pemilu 2019. Sebaliknya, menurut Putusan MA No. 65 P/HUM/2018 terkait dengan larangan bagi pengurus partai sebagai balon anggota DPD tidak memiliki kekuatan hukum mengikat jika diberlakukan pada pada Pemilu 2019. Kedua, adanya perbedaan pemberlakuan larangan bagi pengurus partai sebagai balon anggota DPD pada Pemilu 2019 disebabkan adanya perbedaan dalam menafsirkan tahap pencalonan anggota DPD.

\section{Saran}

Kepada Mahkamah Konstitusi tetap melakukan tugas dan fungsionya secara konsisten dan presisten sesuai dengan amanah konstitusi, kepada pemerintah dan Komisi Pemilihan Umum harus ada sinergitas di dalam menegakan ketentuan undang-undang pemilu kiranya Putusan Mahkamah Konstitusi dapat dijalankan dengan sebaik-baiknya.

44 Wawancara dengan Ketua Komisi Pemilihan Umum (KPU) Arief Budiman pada tanggal 14 Mei 2019.

45 Pan Mohamad Faiz dan Muhammad Reza Winata, Op. Cit., hlm. 551. 


\section{Daftar Pustaka}

\section{Buku}

Abdul Mukthie Fajar, Hukum Konstitusi dan Mahkamah Konstitusi, Konstitusi Press, Jakarta, 2006.

Amiruddin dan H. Zainal Asikin, Pengantar Metode Penelitian Hukum, PT RajaGrafindo Persada, Jakarta, 2004.

Erna Widodo dan Mukhtar, Konstruksi Ke Arah Penelitian Deskriptif, Avyrouz, Yogyakarta, 2000.

M. Yahya Harahap, Hukum Acara Perdata Tentang Gugatan, Persidangan, Penyitaan, Pembuktian, dan Putusan Pengadilan, Sinar Grafika, Jakarta, 2011.

Ridwan HR, Hukum Administrasi Negara, Cetakan ke-15, PT RajaGrafindo Persada, Depok, 2018.

Soerjono Soekanto, Pengantar Penelitian Hukum, UI Press, Jakarta, 1982.

Sudikno Mertokusumo, Hukum Acara Perdata Indonesia, Edisi Revisi, Cahaya Atma Pustaka, Yogyakarta, 2013.

Suharsini Arikunto, Manajemen Penelitian, PT Rineka Cipta, Jakarta, 1993.

Wisnu Jatmiko dkk, Panduan Penulisan Artikel Ilmiah, Fakultas Ilmu Komputer Universitas Indonesia, Depok, 2015.

\section{Jurnal}

Denny Indrayana dan Zainal Arifin Mochtar, "Komparasi Sifat Mengikat Putusan Judicial Review Mahkamah Konstitusi dan Pengadilan Tata Usaha Negara", Jurnal Mimbar Hukum, Volume 19, Nomor 3, Oktober 2007.

Fajar Laksono, dkk., "Implikasi dan Implementasi Putusan Mahkamah Konstitusi Nomor 5/PUUX/2012 tentang SBI atau RSBI”, Jurnal Konstitusi, Volume 10, Nomor 4, Desember 2013.

Maruarar Siahaan, "Peran Mahkamah Konstitusi Dalam Penegakan Hukum Konstitusi”, Jurnal Hukum, Nomor 3, Volume, 16 juli 2009.

Mohammad Agus Maulidi, "Problematika Hukum Implementasi Putusan Final dan Mengikat ahkamah Konstitusi Perspektif Negara Hukum”, Jurnal Hukum Ius Quia lustum, No. 4 Vol. 24 Oktober 2017. 
Pan Mohamad Faiz dan Muhammad Reza Winata, "Respons Konstitusional Larangan Calon Anggota Dewan Perwakilan Daerah sebagai Pengurus Partai Politik", Jurnal Konstitusi, Volume 16, Nomor 3, September 2019.

\section{Internet}

“Jumlah Afiliasi Anggota DPD Dalam Partai Politik”, Indonesian Parliamentary Center, http://ipc.or.id/wp-content/uploads/2017/04/garis.jpg, diakses pada tanggal 18 Oktober 2020.

\section{Peraturan Perundang-Undangan}

Undang-Undang Nomor 15 Tahun 2011 tentang Penyelenggara Pemilihan Umum, Lembaran Negara Republik Indonesia Tahun 2011 Nomor 101, Tambahan Lembaran Negara Republik Indonesia Nomor 5246.

Undang-Undang Nomor 7 Tahun 2017 tentang Pemilihan Umum, Lembaran Negara Republik Indonesia Tahun 2017 Nomor 187, Tambahan Lembaran Negara Republik Indonesia Nomor 6109.

Undang-Undang Nomor 48 Tahun 2009 tentang Kekuasaan Kehakiman, Lembaran Negara Republik Indonesia Tahun 2009 Nomor 157, Tambahan Lembaran Negara Republik Indonesia Nomor 5076.

Undang-Undang Nomor 24 Tahun 2003 tentang Mahkamah Konstitusi, Lembaran Negara Republik Indonesia Tahun 2003 Nomor 98, Tambahan Lembaran Negara Republik Indonesia Nomor 4316 sebagaimana telah diubah terakhir dengan Undang-Undang Nomor 7 Tahun 2020 tentang Perubahan Ketiga Atas Undang-Undang Nomor 24 Tahun 2003 tentang Mahkamah Konstitusi, Lembaran Negara Republik Indonesia Tahun 2020 Nomor 216, Tambahan Lembaran Negara Republik Indonesia Nomor 6554.

Undang-Undang Nomor 14 Tahun 1985 tentang Mahkamah Agung, Tambahan Lembaran Negara Republik Indonesia Tahun 1985 Nomor 73 sebagaimana telah diubah terakhir dengan Undang-Undang Nomor 3 Tahun 2009 tentang Perubahan kedua atas Undang-Undang Nomor 14 Tahun 1985 tentang Mahkamah Agung, Lembaran Negara Republik Indonesia Tahun 2009 Nomor 3, Tambahan Lembaran Negara Republik Indonesia Nomor 4958.

Peraturan Komisi Pemilihan Umum Nomor 7 Tahun 2017 tentang Tahapan, Program, dan Jadwal Penyelenggaraan Pemilihan Umum Tahun 2019 bertanggal 4 September 2017. 
Peraturan Komisi Pemilihan Umum Nomor 5 Tahun 2018 tentang Perubahan Atas PKPU Nomor 7 tahun 2017 tentang Tahapan, Program dan Jadwal Penyelenggaraan Pemilihan Umum Tahun 2019 bertanggal 19 Januari 2018.

Peraturan Komisi Pemilihan Umum Nomor 32 Tahun 2018 tentang Perubahan Kedua Atas PKPU Nomor 7 tahun 2017 tentang Tahapan, Program dan Jadwal Penyelenggaraan Pemilihan Umum Tahun 2019 bertanggal 19 September 2018.

Peraturan Komisi Pemilihan Umum Nomor 14 Tahun 2018 tentang Pencalonan Perseorangan Peserta Pemilu Anggota Dewan Perwakilan Daerah bertanggal 10 April 2018.

Peraturan Komisi Pemilihan Umum Nomor 21 Tahun 2018 bertanggal 17 Juli 2018 tentang Perubahan Atas PKPU Nomor 14 Tahun 2018 tentang Pencalonan Perseorangan Peserta Pemilu Anggota Dewan Perwakilan Daerah.

Peraturan Komisi Pemilihan Umum Nomor 26 Tahun 2018 tentang Perubahan Kedua atas PKPU Nomor 14 Tahun 2018 tentang Pencalonan Perseorangan Peserta Pemilu Anggota Dewan Perwakilan Daerah bertanggal 6 Agustus 2018.

\section{Putusan Pengadilan}

Putusan Mahkamah Konstitusi Nomor 30/PUU-XVI/2018 tanggal 23 Juli 2018 tentang Pengujian Undang-Undang Nomor 7 Tahun 2017 tentang Pemilihan Umum.

Putusan Mahkamah Agung Nomor 65 P/HUM/2018 tanggal 25 Oktober 2018 tentang Permohonan keberatan Hak Uji Materiil terhadap Pembentukan Peraturan Komisi Pemilihan Umum Nomor 26 Tahun 2018 Tentang Perubahan Kedua Atas Peraturan KPU Nomor 14 Tahun 2018 Tentang Pencalonan Perseorangan Peserta Pemilu Anggota Dewan Perwakilan Daerah. 